\title{
ANALISA VARIASI TINGGI KELUARAN TABUNG KOMPRESOR TERHADAP UNJUK KERJA POMPA HIDRAM
}

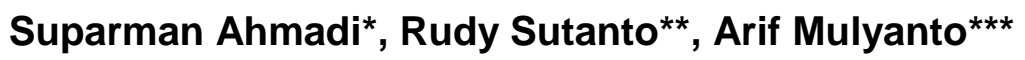 \\ Jurusan Teknik Mesin Fakultas Teknik Universitas Mataram \\ Jln. Majapahit No.62 Mataram Nusa Tenggara Barat Kode Pos: 83125 \\ Telp. (0370) 636087; 636126; ext 128 Fax (0370) 636087
}

\begin{abstract}
Water is one factor that is very important and necessary in the life of living creatures. Therefore, water should be available whenever and wherever in sufficient number, time, and it's quality. The distribution of water in the plateau required an environmentally friendly tool and lower of operational cost. Hydraulic Ram (Hydram) pump is a pump which does not require external energy as the main driving force. This research would observe the effect of discharge input's variation and high variation of the compressor tube output (Air Chamber) toward the efficiency resulting.

The specifications of Hydram pump which is used in this research is a 3-inch compressor tube (Air Chamber) with $60 \mathrm{~cm}$ of height. On the compressor tube there are five high variations output with $10 \mathrm{~cm}$ range in each pump's body. The high levels of water used is 6 meter from the pump and the high water lift (output) used is 9,2 meter. Whereas, the parameter measured in this research are discharge input, discharge output, and the efficiency.

The research result shows that the variation in output which produces high output discharge is greatest at $10 \mathrm{~cm}$ high output is $102,24 \mathrm{ml} / \mathrm{s}$ for input variations discharge 12421,63 m/s, while the output of the lowest discharge generated by high output $50 \mathrm{~cm}$ which is $42,08 \mathrm{ml} / \mathrm{s}$ for input variations discharge 1730,10 ml/s. Whereas the highest efficiency that is 5,084\% higher output obtained from $10 \mathrm{~cm}$ to $1730,10 \mathrm{ml} / \mathrm{s}$ discharge input and the lowest efficiency is $1,023 \%$ derived from $50 \mathrm{~cm}$ high output with input discharge $12421,63 \mathrm{ml} / \mathrm{s}$.
\end{abstract}

Keywords: Hydraulic ram pump, Air chamber, Output height, Input Discharge, Efficiency.

\section{PENDAHULUAN}

Air merupakan salah satu faktor yang sangat penting dan dibutuhkan dalam kehidupan mahluk hidup. Selain untuk kebutuhan perkembangan fisiologis mahluk hidup, air juga menjadi media bagi beragam upaya atau kegiatan mahluk hidup dalam rangka mempertahankan dan atau menghasilkan sesuatu untuk kelangsungan hidupnya. Kebutuhan air yang cukup banyak sering kali menimbulkan permasalahan baru bagi manusia, khususnya bagi 
masyarakat yang tinggal jauh dari sumber air atau berada di tempat yang berada di atas sumber air (Anonim, 2009).

Salah satu upaya untuk memenuhi kebutuhan air, terutama di lokasi yang posisinya lebih tinggi dari pada mata air adalah menggunakan pompa air. Jenis pompa yang lazim digunakan saat ini adalah pompa air bertenaga motor listrik dan pompa yang menggunakan bahan bakar minyak (solar atau bensin). Untuk daerah perkotaan kebutuhan BBM tidak terlalu menjadi masalah. Sementara itu dari data yang berhasil dihimpun bahwa didaerah pedesaan atau daerah terpencil keberadaan BBM sangat langka, bila ada, harganyapun sangat mahal. Untuk mengatasi masalah inilah timbul pemikiran untuk menggunakan pompa air tanpa motor listrik dan pompa yang tidak memerlukan BBM (Sutanto, 2012).

$$
\text { Untuk menyelesaikan }
$$
problem tersebut dapat digunakan pompa yang tidak memerlukan energi luar sebagai sumber tenaga penggerak utama. Pompa Hydraulic Ram (Hydram) adalah sebuah pompa yang tidak memerlukan energi luar sebagai sumber tenaga penggerak utama. Selain tidak memerlukan energi luar sebagai sumber tenaga penggerak utama, pompa hidram juga memiliki kelebihan lain, yaitu: konstruksinya sederhana, tidak memerlukan pelumasan, dapat bekerja kontinyu selama 24 jam tanpa berhenti, pengoperasiannya mudah, biaya pembuatan dan perawatan murah (Siahaan, 2012).

Tujuan dari penelitian ini adalah untuk Mengetahui pengaruh variasi tinggi keluaran tabung kompresor pompa hidram susunan input-katup kompresor (ILK) terhadap efisiensi yang akan dihasilkan, dimana katup keluarannya divariasikan sebanyak lima keluaran dengan jarak yang ditentukan serta mengetahui pengaruh debit input terhadap efisiensi yag dihasilkan

Manfaat yang diharapkan dari penelitian ini adalah dapat digunakan sebagai bahan acuan dalam perancangan ataupun pembuatan pompa hidram yang lebih ekonomis dan efisien baik oleh kalangan sendiri maupun kalangan umum. Bahkan juga dapat digunakan sebagai bahan ajar dalam perancangan dan pembuatan pompa hidram.

\section{LANDASAN TEORI}

Kesimpulan dari penelitian Suarda (2008) tabung udara berfungsi mengurangi daya yang diperlukan oleh pompa. Dari hasil penelitian didapatkan bahwa head tekanan balik di dalam pipa penghantar menurun dari 103,87 m tanpa menggunakan tabung udara menjadi $37,85 \mathrm{~m}$ dengan tabung udara. Selanjutnya, dalam pipa penyalur head tekanan akibat water hammer meningkat dari $0,29 \mathrm{~m}$ tanpa menggunakan tabung udara menjadi 2,9 $\mathrm{m}$ dengan menggunakan tabung udara. Sehingga pemasangan tabung udara dapat meningkatkan efisiensi pompa hidram secara signifikan dari $0.72 \%$ tanpa tabung menjadi $19,45 \%$ dengan tabung udara.

Dalam penelitian yang dilakukan oleh Fane (2012) Berdasarkan data yang didapat yaitu efisiensi pompa terbesar dihasilkan pada variasi pompa hidram konfigurasi tabung paralel yaitu $3,278 \%$, sedangkan efisiensi untuk pompa hidram dengan konfigurasi tabung seri yaitu 
sebesar 2,809\%. Hal ini disebabkan karena pada variasi ini kapasitas pemompaan dan head maksimalnya paling besar sehingga efesiensi yang dihasilkan juga besar.

\subsection{PENGERTIAN FLUIDA}

Fluida adalah suatu zat yang bisa mengalami perubahanperubahan bentuknya secara terusmenerus bila terkena tekanan/gaya geser walaupun relatif kecil atau bisa juga dikatakan suatu zat yang mengalir, artinya fluida dikatakan sebagai zat yang mempunyai partikel yang mudah bergerak dan berubah bentuk tanpa pemisahan massa. Ketahanan fluida terhadap perubahan bentuk sangat kecil sehingga fluida dapat dengan mudah mengikuti bentuk ruang (Lohat, 2009).

\subsection{POMPA HIDRAM}

Pompa hidram atau singkatan dari hidraulic ram berasal dari kata hidro = air (cairan), dan ram = hantaman, pukulan atau tekanan, sehingga terjemahan bebasnya menjadi tekanan air. Jadi pompa hidram adalah sebuah pompa yang energi atau tenaga penggeraknya berasal dari tekanan atau hantaman air yang masuk kedalam pompa melalui pipa. Masuknya air yang berasal dari berbagai sumber air ke dalam pompa harus berjalan secara kontinyu atau terus menerus. Alat ini sederhana dan efektif digunakan pada kondisi yang sesuai dengan syara-syarat yang diperlukan untuk operasinya. Dalam kerjanya alat ini, tekanan dinamik yang ditimbulkan memungkinkan air mengalir dari tinggi vertical (head) yang rendah ke tempat yang lebih tinggi. tidak terbatas hanya pada penyediaan air untuk kebutuhan rumah tangga, tapi juga dapat digunakan untuk pertanian, peternakan, dan perikanan darat. Karena pompa ini bekerja tanpa menggunakan bahan bakar minyak (BBM) atau tanpa motor listrik maka disebut juga "Pompa Air Tanpa Motor " ( Motorless Water Pump ) dan disingkat PATM.

Pompa hidraulik ram memanfaatkan tenaga aliran air yang jatuh dari tempat suatu sumber dan sebagian dari air itu dipompakan ke tempat yang lebih tinggi. Pada berbagai situasi, penggunaan pompa hidram memiliki keuntungan dibandingkan dengan pompa jenis lainnya, yaitu tidak menggunakan bahan bakar atau tambahan tenaga dari sumber lain, tidak membutuhkan pelumasan, bentuk sederhana, biaya pembuatan serta pemeliharaannya murah dan tidak membutuhkan keterampilan tinggi untuk membuatnya. Pompa ini dapat bekerja dua puluh empat jam. (Anonim5, 2009).

\subsection{SISTEM KERJA POMPA HIDRAM}

Merubah kecepatan energi kinetik aliran menjadi daya angkat untuk memindahkan air pada suatu ketinggian tertentu. Cara kerja pompa hidram diawali dengan aliran air dari sumber masuk melalui pipa pemasukan atau pipa penghubung dan keluar dari katup limbah. Gaya tekan air yang masuk ke dalam pompa akan mendorong katup tersebut sehingga memaksa katup tersbut menutup dan menghentikan aliran di pipa pemasukan. Kondisi ini menyebabkan adanya gaya tekan dari pipa pemasukan dan memaksa 
air untuk mengalir ke pipa pengeluaran dengan tekanan tinggi sehingga mampu dialirkan ke lokasi yang lebih tinggi (Balitbang PU, 2005).

\subsection{PALU AIR (WATER HAMMER)}

Gejala palu air terjadi karena adanya air dari reservoir dialirkan melalui pipa secara tiba-tiba dihentikan oleh suatu penutupan katup, maka energi potensial akan berubah menjadi energi kinetik, sehingga serangkaian gelombang tekanan positif dan negatif akan bergerak maju mundur di dalam pipa sampai terhenti akibat gesekan.

Pompa hidram bekerja berdasarkan palu air, ketika suatu aliran fluida dalam pipa dihentikan secara tiba-tiba misalnya dengan menutup katup dengan sangat cepat, sehingga akan membentur katup dan menimbulkan tekanan yang melonjak disertai fluktuasi tekanan di sepanjang pipa untuk beberapa saat.

\section{Sebagian}

gelombang

tekanan tersebut akan menjadi arus balik ke arah reservoir dan ini berarti terjadi penurunan tekanan pada sistem pompa sehingga klep penghantar tertutup kembali sedangkan klep limbah membuka kembali. Akibat dari pembebasan gelombang tekanan tersebut kembali lagi arus massa air dari reservoir menuju pompa akan menekan naik klep limbah sehingga terjadi penutupan tiba-tiba yang mengakibatkan terjadi proses palu air. Proses yang terjadi berulangulang inilah yang mendorong naik air ke pipa penghantar untuk kemudian diteruskan ke bak penampung (Suarda, 2008).

\subsection{EFISIENSI POMPA HIDRAM}

Kemampuan pompa hidram dapat direfresentatifkan dalam bentuk efisiensi pompa, adapun formula dari efisiensi tersebut didapatkan dari penurunan rumus dari prinsip Hidrolika Bernouli dan water hammer, formula yang diturunkan adalah:

$$
\eta=\frac{Q_{2}}{Q_{1}} \times \frac{H_{2}}{H_{1}} \times 100 \%
$$

Dimana:

$$
\begin{aligned}
& \eta=\text { Efisiensi pompa } \\
& \text { hydram } \\
& Q_{1}=\text { Debit input }(\mathrm{m} / \mathrm{s}) \\
& Q_{2} \quad=\text { Debit output }(\mathrm{m} \ell / \mathrm{s}) \\
& H_{1}=\text { Tinggi input }(\mathrm{m}) \\
& H_{2} \text { = Tinggi output }(\mathrm{m})
\end{aligned}
$$

\section{METODE PENELITIAN}

dua macam venelitian ini ada digunakan, yaitu:

1. Variabel Terikat

Untuk variabel terikat dalam pengujian ini adalah : Debit output,Debit input,dan Efisiensi

2. Variabel bebas

Adapun variabel bebas dalam penelitian ini, yaitu tabung kompresor pompa hidram dengan lima variasi ketinggian keluaran. 


\subsection{RANCAGAN PENELITIAN}

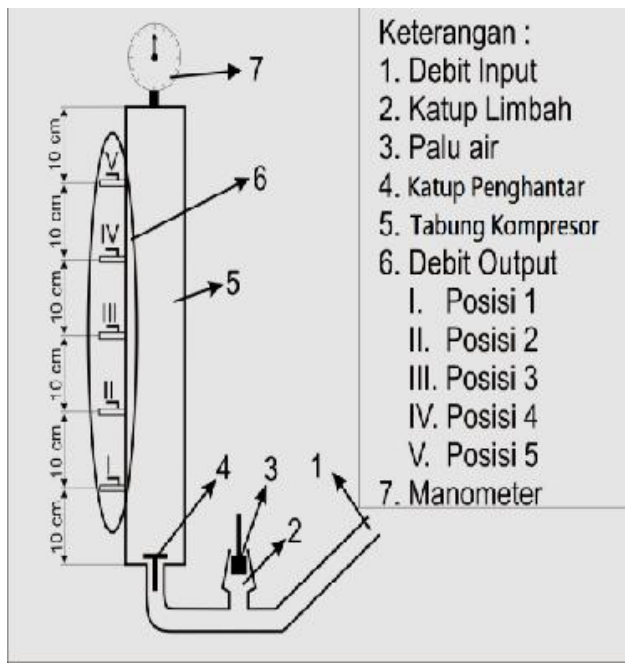

Gambar 3.1 pompa hidram dengan 5 variasi keluaran tabung kompresor

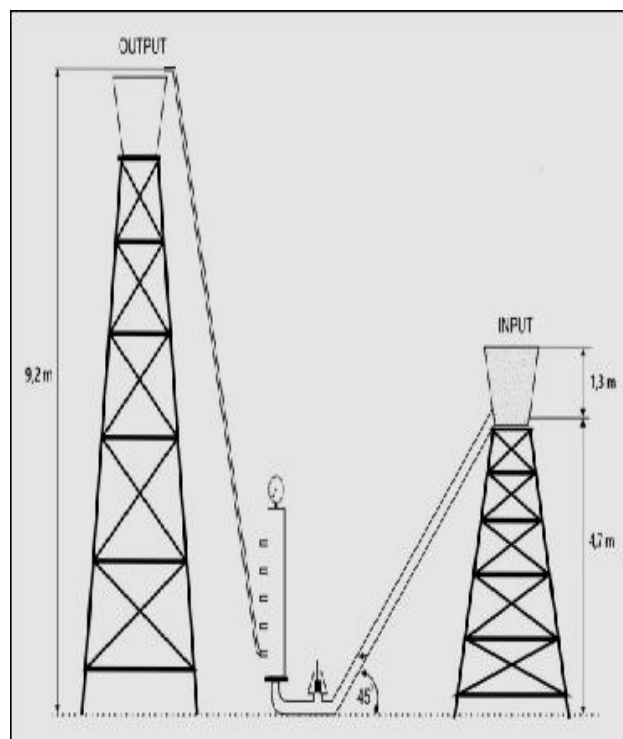

Gambar 3.2 instalasi pompa hidram

\subsection{TAHAP PENGUJIAN}

1. Mengatur tinggi terjunan dan sudut terjunan sesuai dengan perlakuan yang diinginkan

2. Menghubungkan sumber air ke pompa dengan menggunakan pipa yang telah disiapkan

3. Mengalirkan air dari sumber air ke pompa yang sudah disiapkan dan dipasang pada dudukannya

4. Mengukur tekanan input, tekan output, tekanan tabung kompresor, debit air input, dan debit ar output

5. Pengujian tersebut kemudian diulangi pada masing masing variasi keluaran pada tabung kompresor.

\section{HASIL DAN PEMBAHASAN}

Pada penelitian ini tinggi input atau sumber air $\left(H_{1}\right)$ yang digunakan adalah 6 meter dari pompa sedangkan tinggi output $\left(H_{2}\right)$ yang digunakan adalah 9,2 meter, untuk sudut dari terjunan sendiri digunakan sudut $45^{\circ}$. Adapun diameter pipa input yang digunakan adalah 1,5 inchi dan pipa keluaran 0,5 inchi, sedangkan untuk tabung kompresor digunakan pipa galvanis dengan ukuran 3 inchi dan tinggi tabung $60 \mathrm{~cm}$. Pada tabung kompresor dibuat lima variasi keluaran dimana jarak antara variasi yang digunakan masing masing $10 \mathrm{~cm}$.

Pada penelitian ini juga digunakan beberapa variasi debit input $\left(Q_{1}\right)$ untuk semua variasi tinggi keluaran dari tabung kompresor itu sendiri. Adapun beberapa variasi debit input $\left(Q_{1}\right)$ yang digunakan adalah 1730,10 $\mathrm{ml} / \mathrm{s} ; 3130,05 \mathrm{ml} / \mathrm{s} ; 6260,64 \mathrm{ml} / \mathrm{s}$; $9200,91 \mathrm{~m} / \mathrm{s} ;$ dan 12421,63 $\mathrm{m} \ell / \mathrm{s}$. Untuk debit input $\left(Q_{1}\right)$ sendiri dalam penelitian ini diperoleh dari bukaan keran yang dipasang sebelum pompa hidram dimana bukaan keran digunakan beberapa sudut diantaranya $30^{\circ} ; 45^{\circ}, 60^{\circ}$; $75^{\circ} ; 90^{\circ}$.

Proses pengambilan data dilakukan dengan tiga kali pengulangan untuk setiap variasi yang digunakan, dari tiga kali pengulangan tersebut diambil rata- 
rata untuk hasil yang akan diguakan. Berdasarkan penelitian yang sudah dilakukan maka diperoleh beberapa data seperti debit input $\left(Q_{1}\right)$, debit output $\left(Q_{2}\right)$ dan efisiensi ( ).

Unjuk kerja pompa yang akan dianalisa pada penelitian ini adalah debit air output $\left(Q_{2}\right)$ untuk semua variasi debit input dan tinggi keluaran tabung kompresor, dan ( ) efisiensi untuk semua variasi debit dan tabung kompresor.

\subsection{DEBIT OUTPUT $\left(Q_{2}\right)$}

Debit output $\left(Q_{2}\right)$ merupakan hasil keluaran yang diperoleh dari pompa hidram, yaitu dari pipa penghantar yang ada pada tabung kompresor. Data yang digunakan merupaka hasil rata-rata dari tiga kali pengulangan dalam proses pengambilan data.

4.1.1 Hubungan antara variasi debit input dan variasi tinggi keluaran tabung kompresor terhadap debit output yang dihasilkan

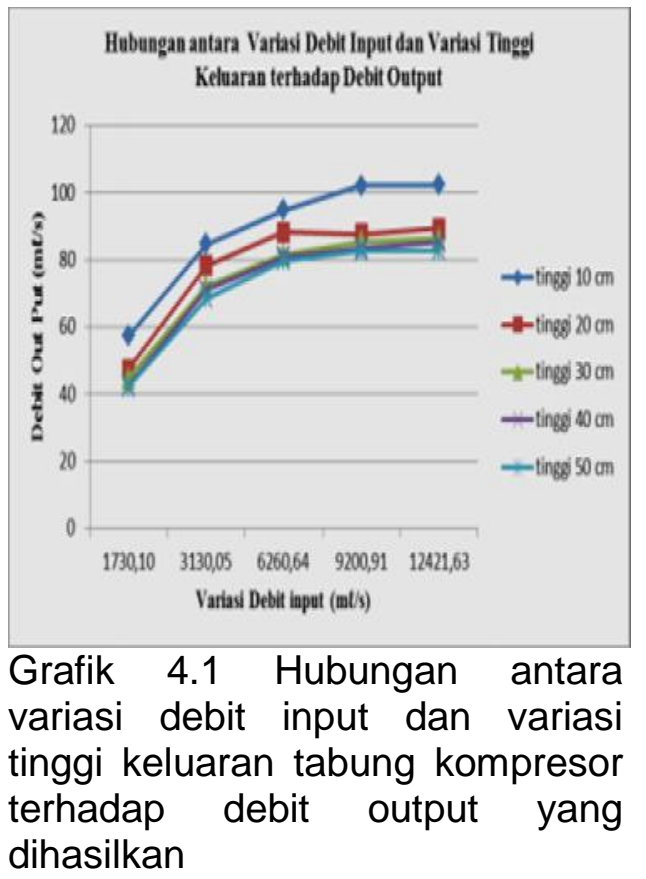

Pada grafik 4.1 tersebut menunjukkan bahwa debit output $\left(Q_{2}\right)$ yang paling besar dihasilkan oleh tinggi keluaran $10 \mathrm{~cm}$, ini berlaku untuk setiap variasi debit input, sedangkan debit output $\left(Q_{2}\right)$ yang paling rendah diperoleh dari tinggi keluaran $50 \mathrm{~cm}$ untuk setiap variasi debit input. Hal ini disebabkan karena pompa hidram merubah kecepatan energi kinetik menjadi daya angkat untuk memindahkan air pada ketinggian 9,2 meter. Kerja pompa hidram diawali dengan aliran air dari sumber masuk melalui pipa pemasukan atau pipa penghubung dan keluar dari katup limbah, ketika debit input yang masuk besar maka gaya tekan air yang masuk ke dalam pompa akan meningkat dan mendorong katup limbah sehingga memaksa katup limbah tertutup dan menghentikan aliran di pipa pemasukan. Kondisi ini menyebabkan adanya gaya tekan yang tinggi dari pipa pemasukan dan memaksa air untuk mengalir ke pipa penghantar dengan tekanan tinggi sehingga mampu dialirkan ke tempat yang lebih tinggi dengan volume yang cukup besar, begitu juga untuk debit input yang rendah. 
4.1.2 Hubungan antara Variasi Tinggi Keluaran tabung Kompresor dan Variasi Debit Input terhadap Debit Output yang dihasilkan

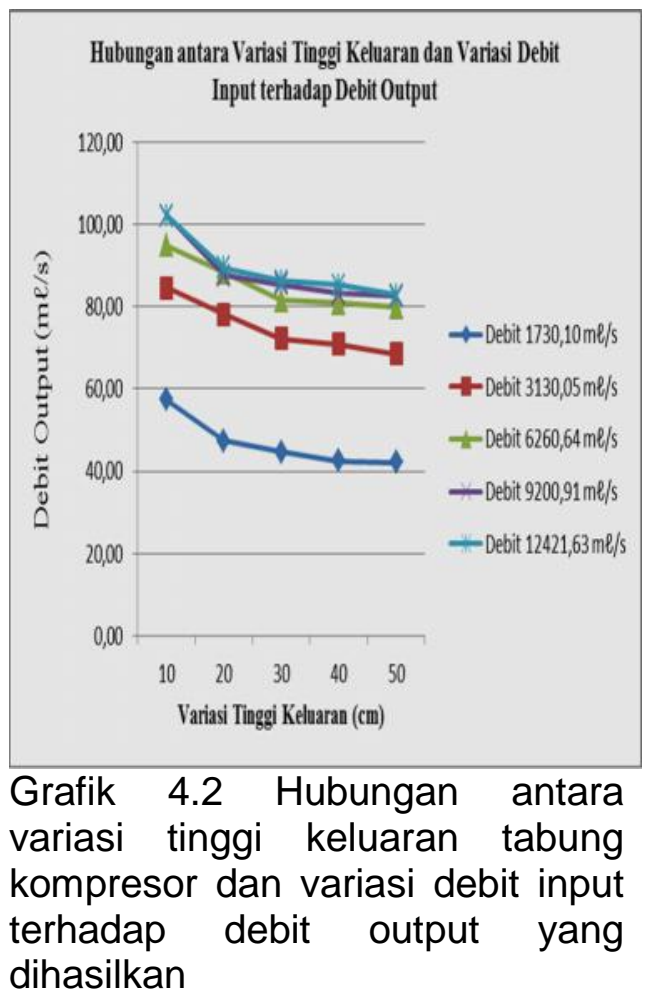

Pada grafik 4.2 hasil penelitian variasi tinggi keluaran tabung kompresor dan variasi debit input menghasilkan debit output paling besar pada keluaran $10 \mathrm{~cm}$ untuk semua variasi debit yang digunakan. Sedangkan untuk debit output yang paling rendah dihasilkan oleh tinggi keluaran 50 $\mathrm{cm}$ untuk semua variasi debit input yang digunakan. Hal ini disebabkan karena ketika posisi keluaran tabung kompresor berada pada tinggi $10 \mathrm{~cm}$, maka volume air pada tabung kompresor hampir sama dengan volume udara yang akan dimampatkan oleh air, sehingga ketika udara sudah berada pada tekanan tertentu maka air pada tabung kompresor akan terdorong keluar oleh udara yang bertekanan tadi melewati pipa penghantar dengan volume yang cukup besar. Sedangkan untuk tinggi keluaran 50 $\mathrm{cm}$ pada tabung kompresor untuk level air di dalamnya lebih banyak dibandingkan udara yang akan dimampatkan, sehingga ketika udara sudah bertekanan akibat dorongan air maka air akan terdorong keluar dengan volume yang rendah dibndingkan pada tinggi keluaran $10 \mathrm{~cm}$.

\subsection{EFISIENSI ( )}

Efisiensi diperoleh dari perbandingan debit output $\left(Q_{2}\right)$ dan debit input $\left(Q_{1}\right)$ dikalikan dengan perbandingan head ketinggian output $\left(\mathrm{H}_{2}\right)$ dan head ketinggian $\left(H_{1}\right)$ sumber air.

\subsubsection{Hubungan antara Variasi Debit Input dan Variasi Tinggi Keluaran Tabung Kompresor terhadap Efisiensi yang dihasilkan}

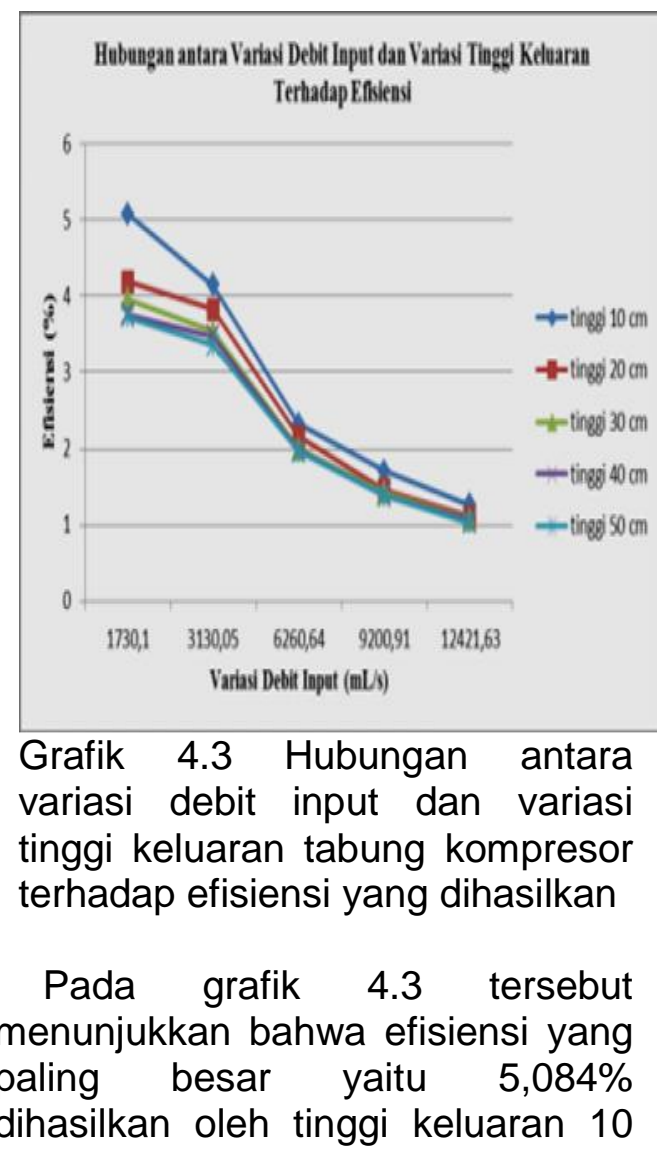


$\mathrm{cm}$, sedangkan efisiensi yang paling kecil yaitu 1,023\% diperoleh dari tinggi keluaran $50 \mathrm{~cm}$, namun di sini terlihat bahwa efisiensi tertinggi jika dilihat dari variasi debit input ditunjukkan oleh debit yang paling rendah yaitu $1730,10 \mathrm{~m} / \mathrm{s}$ sedangkan efisiensi terendah dihasilkan oleh debit input yang paling besar yaitu $12421,63 \mathrm{~m} / \mathrm{s}$. Hal ini disebabkan oleh kecepatan aliran pada saluran input yang berpengaruh terhadap kerja katup limbah. Semakin besar debit input yang masuk atau semakin tinggi kecepatan aliran maka katup limbah akan semakin cepat bergerak sehingga air yang terbuang cukup banyak dibandingkan air output yang dihasilkan.

\subsubsection{Hubungan antara Variasi Tinggi Keluaran Tabung Kompresor dan Variasi Debit Input terhadap Efisiensi yang dihasilkan}

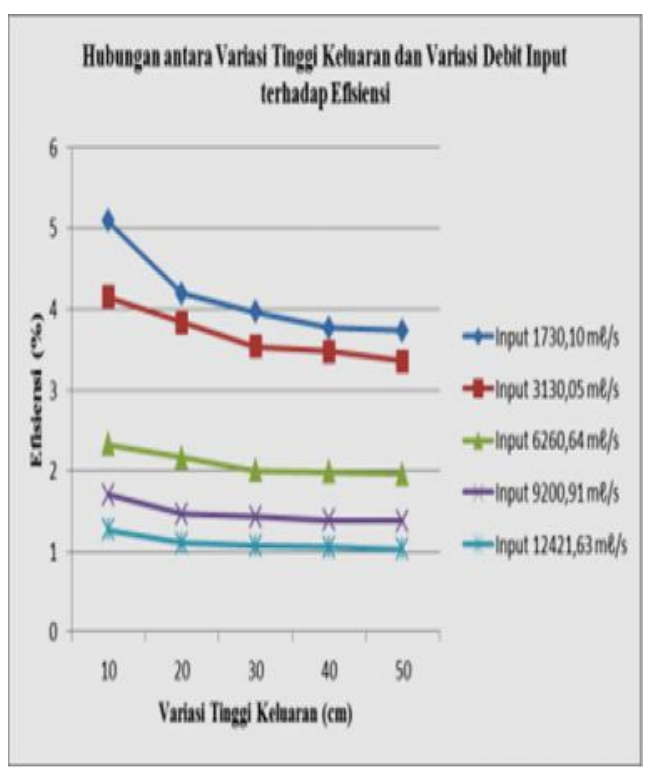

Grafik 4.4 Hubungan antara variasi tinggi keluaran tabung kompresor dan variasi debit input terhadap efisiensi yang dihasilkan
Pada grafik 4.4 dapat dilihat efisiensi yang paling tinggi ditunjukkan oleh variasi tinggi keluaran yang pertama untuk semua variasi debit input. Hal ini disebabkan karena semakin tinggi keluaran yang digunakan maka volume debit output yang dihasilkan akan semakin berkurang dan semakin bawah tinggi keluaran yang digunakan maka volume debit output yang dihasailkn akan semakin besar untuk semua variasi debit input. Hal ini akan sangat berpengaruh terhadap efisiensi yang akan dihasilkan.

\section{KESIMPULAN}

Berdasarkan hasil perhitungan dan analisa data yang telah dilakukan pada bab sebelumnya, maka dapat ditarik kesimpulan diantaranya :

1. Dari hubungan antara variasi debit input dan variasi tinggi keluaran terhadap debit output diperoleh debit output yang paling rendah pada variasi debit input 1730,10 $\mathrm{m} \ell / \mathrm{s}$ untuk setiap variasi tinggi keluaran yang digunakan, sedangkan debit output yang paling besar dihasilkan pada variasi debit input 12421,63 $\mathrm{ml} / \mathrm{s}$. Artinya semakin besar debit input yang masuk, maka semakin besar pula debit output yang akan dihasilkan, dengan demikian dapat dikatakan bahwa debit input $\left(Q_{1}\right)$ berbanding lurus dengan debit output $\left(Q_{2}\right)$.

2. Dari hubungan antara variasi tinggi keluaran dengan variasi debit input terhadap debit output diperoleh kesimpulan bahwa semakin tinggi variasi keluaran tabung kompresor pompa hidram, maka semakin 
rendah debit output $\left(Q_{2}\right)$ yang akan dihasilkan untuk setiap variasi debit input $\left(Q_{1}\right)$ yang digunakan.

3. Dari hubungan variasi debit input dan variasi tinggi keluaran tabung kompresor pada penelitian ini, efisiensi yang paling besar diperoleh pada debit input $\left(Q_{1}\right)$ yang paling rendah yaitu 1730,10 $\mathrm{m} \ell / \mathrm{s}$ untuk setiap variasi tinggi keluaran tabung kompresor yang digunakan, sedangkan efisiensi paling rendah diperoleh dari debit input $\left(Q_{1}\right)$ yang paling besar yaitu 12421,63 $\mathrm{m} / \mathrm{s}$ untuk setiap variasi tinggi keluaran tabung kompresor yang digunakan.

4. Dari hubungan antara variasi tinggi keluran dan variasi debit input $\left(Q_{1}\right)$ terhadap efisiensi dapat disimpulkan bahwa semakin tinggi keluaran tabung kompresor, maka semakin rendah efisiensi yang dihasilkan untuk semua variasi debit input $\left(Q_{1}\right)$ yang digunakan. Pada penelitin ini diperoleh efisiensi yang paling besar pada variasi tinggi keluaran $10 \mathrm{~cm}$ untuk semua variasi debit input $\left(Q_{1}\right)$ yang digunakan, sedangkan efisiensi paling rendah diperoleh dari tinggi keluaran $50 \mathrm{~cm}$ untuk semua variasi debit input $\left(Q_{1}\right)$ yang digunakan.

5. Setelah dilihat dari beberapa hubungan di atas kesimpulan terakhir yang dapat diambil adalah tinggi keluaran tabung kompresor $\quad 10 \quad \mathrm{~cm}$ menghasilkan debit output $\left(Q_{2}\right)$ dan efisiensi yang paling besar untuk semua variasi debit input $\left(Q_{1}\right)$ dan variasi tinggi keluaran tabung kompresor pompa hidram yang digunakan.

\section{DAFTAR PUSTAKA}

[1] Anonim, 2009, Dirjen Pengelolaan Air dan Lahan Departemen Pertanian, Pedoman Teknis Pengembangan Irigasi Pompa Hidram. Jakarta.(diunduh pada tanggal 28 Maret 2013).

[2] Fane, D.S., 2012, Pengaruh Konfigurasi Tabung

Kompresor Terhadap Unjuk Kerja Pompa Hidram, Jurusan Teknik Mesin Fakultas Teknik Universitas Mataram, Mataram.

[3] Lohat, A.S., 2009, Fluida Statis Untuk SMA Kelas XI, Program Studi Pendidikan Fisika Universitas Sanata Dharma, Yogyakarta.

[4] Siahaan, P., 2012, Rancang Bangun Dan Uji Eksperimental Pengaruh Variasi Panjang Driven Pipe Dan Diameter Air Chamber Terhadap Efisiensi Pompa Hidram, Jurusan Teknik Mesin Universitas Sumatra Utara, Medan.

[5] Streeter, Viktor L. Wylie, E. Benjamin, Bedford, Keith W., 1998. Fluid Mechanic, Singapore : Mc Graw Hill.

[6] Suarda, M. dan Wirawan, IKG., 2008, Kajian Eksperimental Pengaruh Tabung Udara Pada Head Tekanan Pompa Hidram, Universitas Udayana. Bali.

[7] Sutrisno B., 2009, Analisa Perhitungan efisiensi dalam Perencanaan Pompa Tanpa Mesin, Jurusan Teknik Mesin 
Universitas Mataram, Mataram.

[8] Sutanto, R. dan Wirawan, M., 2012, Analisa Pengaruh Variasi Susunan Terhadap Kemampuan Unjuk Kerja Pompa Hidram Ditinjau Dari Aspek Tinggi Terjunan, Jurusan Teknik Mesin Universitas Mataram, Mataram. 